\title{
A METHODOLOGY FOR ASSESSING AND MANAGING BIODIVERSITY IN STREET TREE POPULATIONS: A CASE STUDY
}

\author{
by Michael F. Galvin
}

\begin{abstract}
As a consequence of compacted soils, impervious surfaces, heat irradiation, pollution, and other stresses, urban trees have an average expected service life of 10 to 25 years. Most public agency budgets for street tree replacement and maintenance are declining. Public tree managers need tools to prolong the service life of street tree populations while reducing the need for maintenance activities (including pruning and pest management). Many jurisdictions rely on "approved tree" lists, but these often contain large numbers of species generally unavailable in a given area, and filters for diversity are seldom part of these documents. To avoid catastrophic losses and pest outbreaks associated with virtual monocultures, the Maryland Department of Natural Resources has developed a methodology for assessing biodiversity in existing populations. An inventory is taken. The results of the inventory are broken down taxonomically by family, genus, and species; The results are then analyzed, with target levels established as follows: no more than $30 \%$ of any one family, $20 \%$ of one genus, or $10 \%$ of one species should be present. Based on the results of the assessment, recommendations are made as a tool for use in future replacement contracts to bring about the desired species composition.
\end{abstract}

Key Words. Biodiversity; street tree populations; street tree inventory.

The benefits of trees in urban or populated areas are well documented. They are variable and far reaching, including improving urban aesthetics, improving wildlife habitat (Schwaab et al. 1995), sequestering carbon and removing pollutants from the atmosphere (McPherson et al. 1994), reducing building energy use for cooling and heating (Akbari et al. 1992), mitigating the "heat island" effect through evapotranspiration and shading (United States Department of Energy 1992), and reducing domestic violence (Sullivan and Kuo 1996). However, as a consequence of compacted soils, limited rooting volume, impervious services, heat irradiation, pollution, and other stresses, urban trees have an average expected service life of 10 to 25 years (Urban 1989). Though this situation would indicate a need for significant maintenance and replacement funding to maintain street tree canopy in urban areas, the average municipal tree budget has dropped from $\$ 4.14$ per capita in the year 1986 to $\$ 2.49$ per capita in 1994 (amounts have been adjusted for inflation for the period described), a $40 \%$ reduction (International Society of Arboriculture 1995). With increased management needs and reduced funding available for management, public agency tree managers need tools that will allow them to prolong the service life of public street tree populations while reducing the amount of tree maintenance, tree removal, and tree replacement needed.

The problems encountered when street tree populations consist of monocultures or virtual monocultures have been demonstrated by the major losses experienced by jurisdictions that over planted American elm (Ulmus americana) or 'Bradford' pear (Pyrus calleryana 'Bradford'). In the case of American elm, huge losses were experienced with the spread of Dutch elm disease (Ophiostoma ulmi) (Nannini et al. 1998). 'Bradford' pear was bred for a number of characteristics, including disease resistance; however, the tree tends to grow with a structural defect whereby multiple primary branches originate from a single point on the main stem, resulting in included bark, multiple codominants, and large limb or whole tree failure as the tree matures. This cultivar became a maintenance problem in many areas (W.L. Ackerman 1995, personal communication; Sissini et al. 1995).

These cases, and others like them, have shown that as most serious pests or problems are specific to certain families, genera, or species of plants, a key to sustainability in urban forests lies not in the selection of any single cultivar with a particular set of characteristics but in biological diversity within populations in order to minimize plant maintenance needs and losses. 


\section{METHODS}

Methods for applying models for urban forest sustainability have been described (Clark et al. 1997; Clark and Matheny 1998). Urban forest management plans have also been generated in some jurisdictions (McPherson and Luttinger 1998), but the methodology is not as standardized as is that for traditional forest management plans.

In the spring of 1996, the Maryland Department of Natural Resources-Forest Service began an effort to establish a procedure for generating urban forest management plans in Maryland. Using the United States Department of Agriculture-Forest Service's An Ecosystem-Based Approach to Urban and Community Forestry (USDA-Forest Service and Center for Urban Forestry 1994) as a foundation, the process of identifying components to incorporate into the overall plan was undertaken These items included a public tree inventory, along with a street tree biodiversity analysis and integrated pest management recommendations based on the inventory data.

\section{SITE SELECTION}

Mount Rainier, Maryland, was selected as the pilot site for the program. The city has an established and active tree commission; the city's mayor, town administrator, and public works director are all involved with and supportive of the city's urban forestry programs. They have demonstrated their commitment by the city's recognition by the National Arbor Day Foundation and the State Forester as a Tree City USA since 1989.

Mount Rainier is a municipality in a highly urbanized area in eastern metropolitan Washington, DC, directly abutting the District of Columbia. Located in Prince George's County (population approximately 750,000), Mount Rainier's population is 7,950 . The jurisdiction maintains approximately 11 mi $(18 \mathrm{~km})$ of roadway, on which the street trees described in the inventory are found. The area is predominantly residential and is dominated by detached single-family homes; most streets have threephase utility lines with cross-arm construction on at least one side of the street and tree lawn widths of from 3 to $4 \mathrm{ft}(0.9$ to $1.2 \mathrm{~m})$. These factors limit the suitable species for much of the city's potential street tree planting sites to small scale trees, or mediumscale trees with decurrent branching.

\section{SITE INVENTORY}

The trees were inventoried between June 12 and June 21,1996 . The inventory was conducted by an intern under the supervision of a Maryland DNR Forest Service Chief Ranger. The following information was recorded: street name, address, tree type, tree dbh, tree condition (good, fair, poor, dead), presence of overhead utility lines, presence of sidewalks, presence of stakes requiring removal, and comments. The jurisdiction later obtained a copy of TreeKeeper Jr. ${ }^{\circledR}$ tree management software for managing the data obtained in the inventory.

\section{DATA ASSESSMENT}

Frank Santamour has previously described a method for managing diversity in urban plantings; this is referred to as "the 10-20-30 formula"(Santamour 1990). The formula states that for maximum protection against pest outbreaks, the urban forest should contain no more than $10 \%$ of any single tree species, no more than $20 \%$ of any tree genus, and no more than $30 \%$ of any tree family.

The data collected in the inventory were broken down and tallied by species, genus, and family. The results are shown in Figure 1 and Table 1. Recommendations were then made for future species composition, and pest management recommendations were provided based on present species composition.

\section{RECOMMENDATIONS}

The analysis showed, with one notable exception, a fairly well-balanced population. Use of red maple (Acer rubrum) should be suspended until population

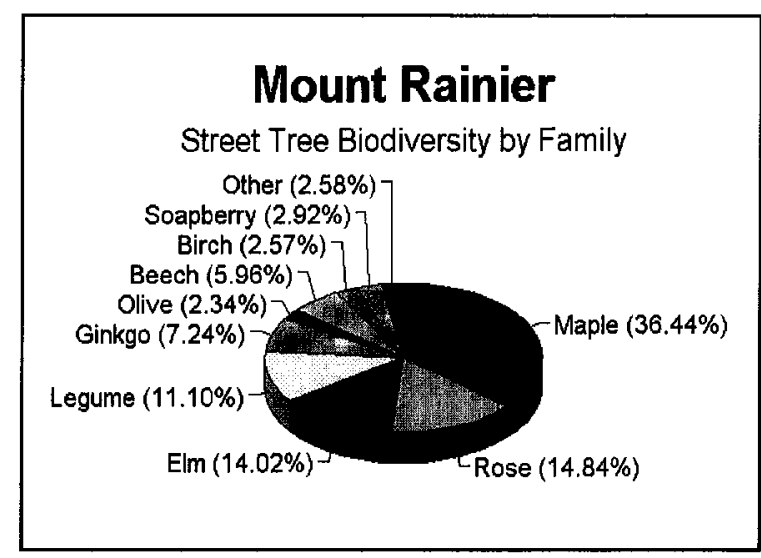

Figure 1 . Street tree diversity by family. 
Table 1. Street tree population by family, genus, and species.

\begin{tabular}{|c|c|c|c|c|c|c|}
\hline Family & $\begin{array}{l}\% \text { of } \\
\text { total }\end{array}$ & Genus & $\begin{array}{l}\% \text { of } \\
\text { total }\end{array}$ & Species & $\begin{array}{l}\text { \# of } \\
\text { trees }\end{array}$ & $\begin{array}{l}\% \text { of } \\
\text { total }\end{array}$ \\
\hline Aceraceae & & Acer & & rubrum & 293 & 34.23 \\
\hline Aceraceae & & Acer & & saccharinum & 14 & 1.64 \\
\hline Aceraceae & & Acer & & saccharum & 2 & 0.23 \\
\hline Aceraceae & & Acer & & palmatum & 1 & 0.12 \\
\hline Aceraceae & 36.45 & Acer & 36.45 & platanoides & 2 & 0.23 \\
\hline Rosaceae & & Pyrus & 9.46 & calleryana & 81 & 9.46 \\
\hline Rosaceae & & Prunus & & unknown & 44 & 5.14 \\
\hline Rosaceae & 14.84 & Prunus & 5.37 & cerasifera & 2 & 0.23 \\
\hline Ulmaceae & & Utmus & 11.80 & americana & 101 & 11.80 \\
\hline Ulmaceae & 14.02 & Zelkova & 2.22 & serrata & 19 & 2.22 \\
\hline Leguminosae & & Sophora & 2.80 & japonica & 24 & 2.80 \\
\hline Leguminosae & & Gleditsia & 7.71 & triacanthos & 66 & 7.71 \\
\hline Leguminosae & 11.10 & Cercis & 0.58 & canadensis & 5 & 0.58 \\
\hline Ginkgoaceae & 7.24 & Ginkgo & 7.24 & biloba & 62 & 7.24 \\
\hline Fagaceae & & Quercus & & rubra & 22 & 2.57 \\
\hline Fagaceae & & Quercus & & phellos & 25 & 2.92 \\
\hline Fagaceae & & Quercus & & palustris & 3 & 0.35 \\
\hline Fagaceae & 5.96 & Quercus & 5.96 & rubra borealis & 1 & 0.12 \\
\hline Sapindaceae & 2.92 & Koelreuteria & 2.92 & paniculata & 25 & 2.92 \\
\hline Betulaceae & 2.57 & Carpinus & 2.57 & caroliniana & 22 & 2.57 \\
\hline Oleaceae & & Fraxinus & 1.40 & pennsylvanica & 12 & 1.40 \\
\hline Oleaceae & 2.34 & Syringa & 0.93 & reticulata & 8 & 0.93 \\
\hline Hamamelidaceae & 1.17 & Liquidambar & 1.17 & styraciflua & 10 & 1.17 \\
\hline Malvaceae & 0.35 & Hibiscus & 0.35 & syriacus & 3 & 0.35 \\
\hline Platanaceae & 0.35 & Platanus & 0.35 & $\times$ acerifolia & 3 & 0.35 \\
\hline Bignoniaceae & 0.23 & Catalpa & 0.23 & bignonioides & 2 & 0.23 \\
\hline Cornaceae & 0.12 & Cornus & 0.12 & florida & 1 & 0.12 \\
\hline Cupressaceae & 0.12 & $\times$ Cupressocyparis & 0.12 & leylandii & 1 & 0.12 \\
\hline Nyssaceae & 0.12 & Nyssa & 0.12 & sylvatica & 1 & 0.12 \\
\hline Salicaceae & 0.12 & Salix & 0.12 & $a l b a$ & 1 & 0.12 \\
\hline
\end{tabular}

levels account for a maximum of $50 \%$ of all maples (currently 94\%) and 10\% of total street trees (currently $33 \%$ ). Maples should account for no more than $20 \%$ of the total street tree population. When the maple population dips below these levels, replacement should be undertaken with a variety of species rather than continue over-reliance on $A$. rubrum.

Current callery pear (Pyrus calleryana) levels should not be exceeded. This is a known problem species and is present at the maximum recommended level. Purpleleaf plum (Prunus cerasifera
'Atropurpurea') may be increased to up to $10 \%$ of total population.

As American elm levels decline, they may be replaced with resistant hybrids, zelkovas (Zelkova serrata, or lacebark elms (Ulmus parvifolia), while maintaining Ulmus levels at no more than $20 \%$ of the total population and zelkova populations at no more than $50 \%$ of Ulmus population.

Honeylocust (Gleditsia triacanthos) (7.52\%) and ginkgo (Ginkgo biloba) (7.06\%) may be increased moderately to $10 \%$ of the total population. There is a 
Table 2. Recommended species for future street tree plantings in Mount Rainier.*

\begin{tabular}{|c|c|c|}
\hline Family & Genus & Species \\
\hline Aceraceae & Acer & buergerianum \\
\hline Aceraceae & Acer & ginnala \\
\hline Aceraceae & Acer & palmatum \\
\hline Betulaceae & Ostrya & virginiana \\
\hline Cornaceae & Cornus & alternifolia \\
\hline Hippocastanaceae & Aesculus & pavia \\
\hline Leguminosae & Maackia & chinensis \\
\hline Leguminosae & Cladrastis & lutea \\
\hline Magnoliaceae & Magnolia & $\begin{array}{l}\text { virginiana; various } \\
\text { cultivars }\end{array}$ \\
\hline Oleaceae & Chionanthus & virginicus \\
\hline Oleaceae & Syringa & reticulata \\
\hline Rosaceae & Amelanchier & $\begin{array}{c}\text { arborea; canadensis; } \\
\text { various cultivars }\end{array}$ \\
\hline Rosaceae & Crataegus & various cultivars \\
\hline Rosaceae & Malus & $\begin{array}{l}\text { various cultivars w/ } \\
\text { persistent fruit }\end{array}$ \\
\hline Rosaceae & Prunus & $\times$ yedoensis \\
\hline
\end{tabular}

*Note: All types listed to be incorporated into current populations within the constraints of the 10-20-30 filter.

noticeable lack of oaks $(5.81 \%)$ in the inventory. This is likely due to the small tree lawns ( 3 to $4 \mathrm{ft}$ [0.9 to $1.2 \mathrm{~m}]$ ) on most streets and the presence of overhead utility lines. Oaks may be planted in any locations where space allows (minimum 4-ft [1.2-m] tree lawn; no overhead utility lines), to a maximum of $20 \%$ of the total population.

Some replacement types not found in the inventory, which are small to medium in scale and will increase diversity, are listed in Table 2.

\section{SUMMARY}

To insure the sustainability of urban forests, management and replacement costs must be minimized. "Approved tree" lists normally have no numerical restrictions; virtually all users could, and in some places do, plant only a small number of the cheapest, most readily available species from such lists. The model provided here requires no special software or equipment other than a reference that includes information on taxonomy. Spreadsheet programs do make the analysis easier; however, this can easily be performed on any of the commonly available spreadsheet packages.

\section{LITERATURE CITED}

Akbari, H., S. Davis, S. Dorsano, J. Huang, and S.Winnett. 1992. Cooling Our Communities: A Guidebook on Tree Planting and Light-Colored Surfacing. Government Printing Office, Washington, DC. 217 pp.

Clark, J.R., N.P. Matheny, G. Cross, and V. Wake. 1997. A model of urban forest sustainability. J. Arboric. 23: $17-30$.

Clark, J.R., and N.P. Matheny. 1998. A model of urban forest sustainability: Application to cities in the United States. J. Arboric. 24:112-120.

International Society of Arboriculture. 1995. Study reveals significant decrease in municipal funding for tree management programs. Arborist News 4(2):31.

McPherson, G.E., D.J. Nowak, and R.A. Rowntree, 1994. Chicago's Urban Forest Ecosystem: Results of the Chicago Urban Forest Climate Project, General Technical Report NE-186. USDA Forest Service, Northeast. For. Exp. Sta., Radnor, PA. 201 pp.

McPherson, E.G., and N. Luttinger. 1998. From nature to nurture: The history of Sacramento's urban forest. J. Arboric. 24:72-88.

Nannini, D.K., R. Sommer, and L.S. Meyers. 1998. Resident involvement in inspecting trees for Dutch Eem disease. J. Arboric. 24:42-46.

Santamour, Frank S., Jr. 1990. Trees for Urban Planting: Diversity, Uniformity, and Common Sense. Proc. 7th Conf. Metropolitan Tree Improvement Alliance (METRIA) 7:57-65.

Schwaab, E.C., L. Alban, J. Riley, R. Rabaglia, and K.E. Miller. 1995. Maryland's Forests: A Health Report. Maryland Department of Natural Resources-Forest Service, Annapolis, MD. 48 pp.

Sissini, S.M., W.C. Zipperer, and A.G. Pleninger. 1995. Impacts from a major ice-storm: street-tree damage in Rochester, New York. J. Arboric. 21:156-167.

Sullivan, W.C., and F.E. Kuo. 1996. Do Trees Strengthen Urban Communities, Reduce Domestic Violence? Forestry Report R8-FR 56. USDA Forest Service, Northeastern Area State and Private Forestry, Urban Forestry Center for the Midwestern States, Evanston, IL. 1 pp.

United States Department of Agriculture Forest Service, State and Private Forestry, Northeastern Area, and Center for Urban Forestry, Morris Arboretum. 1994. An Ecosystem-Based Approach to Urban and Community Forestry. Center for Urban Forestry, Morris Arboretum of the University of Pennsylvania, Philadelphia, PA. 59 pp. 
United States Department of Energy. 1992. Saving Energy by Managing Urban Heat Islands: Something We Can Do About the Weather! U.S. Department of Energy, Washington, DC. 8 pp.

Urban, J.R. 1989. Evaluation of Tree Planting Practices in the Urban Landscape, pp 119-127. In Make Our Cities Safe for Trees: Proc. 4th Urban Forestry Conference. The American Forestry Association, Washington, DC.

Acknowledgements. The author would like to thank the following for their assistance with and support of this project: Marian Honeczy, Forest Conservation Act Coordinator, MD DNR-Forest Service; Laura Donaldson, Ranger, MD DNR-Forest Service; Jason Jackson, Intern, MD DNRForest Service; Johann Klodzen, Chair, Mount Rainier Tree Commission; and the Honorable Fred Sissine, Mayor; Lucille Dickinson, City Manager; and Joe Paul Habada, Public Works Supervisor, of the City of Mount Rainier.

\section{Urban Operations Manager}

Maryland Department of Natural

Resources-Forest Service

Tawes State Office Building, E-1

580 Taylor Avenue

Annapolis, MD 21401

Résumé. En raison des sols compactés, des surfaces imperméables, de la chaleur irradiante, de la pollution et d'autres stress, les arbres en milieu urbain ont une espérance de vie limitée. Avec les budgets d'entretien et de remplacement qui s'amenuisent auprès des organismes publics, les gestionnaires d'arbres ont besoin d'outils pour prolonger la durée de vie utile des populations d'arbres tout en diminuant les activités d'entretien, incluant l'élagage et le contrôle des parasites. Plusieurs décideurs comptent sur des listes d'arbres «approuvées»; mais ces dernières renferment souvent un grand nombre d'espèces généralement non disponibles dans une région donnée. Pour éviter des pertes catastrophiques et des explosions de parasites associées à des monocultures virtuelles, nous avons développé une méthodologie pour évaluer la biodiversité dans les populations existantes. Les résultats de l'inventaire sont décomposés sur une base taxonomique par familles, genres et espèces pour être ensuite analysés en fonction de critères précis: pas plus de 30\% d'arbres doivent être présents au sein d'une même famille, $20 \%$ dans un même genre, ou $10 \%$ d'une même espèce. $\AA$ partir des résultats de l'évaluation, des recommandations sont faites pour être employées lors de futurs remplacements afin d'obtenir la composition en espèces désirée.
Zusammenfassung. Wegen Bodenverdichtungen, ungeeigneten Bodenbelägen, Wärmeabstrahlungen, Verschmutzung und anderen Stressen haben Straßenbäume eine Pflegebedürftigkeit von ca. 10 bis 25 Jahren. Die meisten öfentlichen Budgets für Baumerhaltung und Nachpflanzung werden gekürzt. Die Verantwortlichen für offentliche Bäume benötigen Hilfe, um das Lebensalter der Bäume zu verlängern und gleichzeitig die Pflegeansprüche (Schnitt und Vorbeugemaßnahmen gegen Krankheiten) zu reduzieren. Viele Verwaltungen verlassen sich auf Listen „erprobter Baumarten“, aber diese enthalten oft eine Vielzahl an Arten, die generell für die Gegend ungeeignet sind und Auswahlkriterien für eine Artenvielfalt spielen selten eine Rolle in diesen Listen. Um katastrophale Verluste und Krankheitsausbruch, die mit virtuellen Monokulturen assoziiert werden, zu vermeiden, hat das Department eine methodische Vorgehensweise entwickelt, um die Biodiversität in bestehenden Populationen zu untersuchen. Es wurde eine Inventur vorgenommen. Die Ergebnisse dieser Inventur wurden taxonomisch unterschieden in Familie, Gattung und Art, anschließend analysiert und dann mit folgenden Zielsetzungen etabliert: nicht mehr als $30 \%$ von jeder Familie, $20 \%$ von einer Gattung oder $10 \%$ einer Art sollte präsent sein. Auf der Basis der Ergebnisse dieser Untersuchung, wurden Empfehlungen entwickelt, die bei künftigen Ersatzpflanzungen vertraglich festlegen helfen sollen, daß eine gewünschte Artenzusammensetzung umgesetzt wird.

Resumen. Debido a suelos compactados, superficies impermeables, irradiación de calor, contaminación y otros factores de estrés, los árboles urbanos tienen una limitada esperanza de vida útil. Como la mayoría de los presupuestos de agencias públicas para el reemplazo y mantenimiento de la declinación de los árboles, los manejadores públicos de árboles necesitan herramientas para prolongar la vida útil de poblaciones de árboles, al mismo tiempo que reducir la necesidad de actividades de mantenimiento (incluyendo poda y manejo de plagas). Muchas jurisdicciones confían en listas de "árboles aprobados", pero éstas frecuentemente contienen gran número de especies no disponibles en un área dada. Para evitar pérdidas catastróficas y brotes de plagas asociadas con monocultivos virtuales, hemos desarrollado una metodología para estimar la biodiversidad en poblaciones existentes. Los resultados del inventario están desglosados taxonómicamente; deben presentarse no más de $30 \%$ de cualquier familia, $20 \%$ de un género o $10 \%$ de una especie. Basado en los resultados de la estimación, las recomendaciones son hechas como una herramienta para uso en futuros reemplazos para efectuar la composición de especies deseadas. 